\title{
Dual bloom of green algae and purple bacteria in an extremely shallow soda pan
}

\author{
Kristóf Korponai ${ }^{1} \cdot$ Attila Szabó $^{1} \cdot$ Boglárka Somogyi $^{2} \cdot$ Emil Boros $^{2} \cdot$ Andrea K. Borsodi $^{1} \cdot$ Laura Jurecska $^{1}$. \\ Lajos Vörö̈s ${ }^{2}$ Tamás Felföldi ${ }^{1}$
}

Received: 8 March 2019 / Accepted: 29 April 2019 / Published online: 13 May 2019

(c) The Author(s) 2019

\begin{abstract}
In April 2014, dual bloom of green algae and purple bacteria occurred in a shallow, alkaline soda pan (Kiskunság National Park, Hungary). The water was only $5 \mathrm{~cm}$ deep, in which an upper green layer was clearly separated from a near-sediment purple one. Based on microscopy and DNA-based identification, the upper was inhabited by a dense population of the planktonic green alga, Oocystis submarina Lagerheim, while the deeper layer was formed by purple, bacteriochlorophyllcontaining bacteria, predominated by Thiorhodospira and Rhodobaca. Additional bacterial taxa with a presumed capability of anoxygenic phototrophic growth belonged to the genera Loktanella and Porphyrobacter. Comparing the bacterial community of the purple layer with a former blooming event in a nearby soda pan, similar functional but different taxonomic composition was revealed. Members from many dominant bacterial groups were successfully cultivated including potentially new species, which could be the result of the application of newly designed media.
\end{abstract}

Keywords Soda pan $\cdot$ Purple bacteria $\cdot$ Oocystis $\cdot$ Thiorhodospira $\cdot$ Rhodobaca $\cdot$ Bloom

$\begin{array}{ll}\text { Abbreviations } \\ \text { AAP } & \text { Aerobic anoxygenic phototrophs } \\ \text { BCC } & \text { Bacterial community composition } \\ \text { Bchl } & \text { Bacteriochlorophyll(s) } \\ \text { CFU } & \text { Colony forming units } \\ \text { Chl } a & \text { Chlorophyll } a \\ \text { HMW } & \text { High molecular weight } \\ \text { LMW } & \text { Low molecular weight } \\ \text { NGS } & \text { Next-generation DNA sequencing } \\ \text { NTU } & \text { Nephelometric turbidity unit } \\ \text { OTU } & \text { Operational taxonomic unit } \\ \text { PNSB } & \text { Purple non-sulfur bacteria }\end{array}$

Communicated by A. Oren.

Electronic supplementary material The online version of this article (https://doi.org/10.1007/s00792-019-01098-4) contains supplementary material, which is available to authorized users.

Tamás Felföldi

tamas.felfoldi@ttk.elte.hu

1 Department of Microbiology, ELTE Eötvös Loránd University, Pázmány Péter stny. 1/c., Budapest 1117, Hungary

2 Balaton Limnological Institute, MTA Centre for Ecological Research, Klebelsberg Kuno u. 3., Tihany 8237, Hungary
PSB Purple sulfur bacteria

SRP Soluble reactive phosphorus

TN Total nitrogen

TOC Total organic carbon

\section{Introduction}

Soda lakes have $\mathrm{Na}^{+}$- and $\mathrm{CO}_{3}{ }^{2-} / \mathrm{HCO}_{3}{ }^{-}$-dominated alkaline water, and therefore, they are different from other athalassohaline waters (Boros et al. 2014; Boros and Kolpakova 2018). Soda lakes can be found in almost every continent (Grant 2006; Sorokin et al. 2014; Boros and Kolpakova 2018): in Central Asia (Kulunda Steppe), Inner Asia, East Africa (Eastern Rift Valley), Central Europe (Carpathian Basin) and sporadically in India (Lonar Lake) and North America (Mono Lake and Soap Lake). These alkaline and saline environments range from deep meromictic to shallow lakes, and can be grouped into hypersaline $(>50 \mathrm{~g} / \mathrm{L})$ and less saline water bodies.

Shallow lakes and pans are characteristic features of the semiarid steppe and undergo significant diurnal (mainly temperature and oxygen concentration) and annual (mainly temperature, volume and salinity) changes regarding various physical parameters. According to our current knowledge, 
within Europe, soda lakes could be found exclusively in the Carpathian Basin; their size ranges from small wetlands of few $\mathrm{m}^{2}$ to few hundred ha (Boros et al. 2014, 2017). Most of them are intermittent aquatic systems and have low water transparency (Boros et al. 2017; Somogyi et al. 2017). Two main types of these shallow lakes (which are usually referred as pans) could be distinguished, the 'turbid type' (high amount of suspended solids and usually high concentration of humic substances) and the 'colored type' (relatively low amount of suspended solids and very high concentration of humic substances) (Boros et al. 2017). The 'fluid sediment' concept has been proposed for the turbid water type, as wind induces continuous sediment resuspension due to their extreme shallowness $(<50 \mathrm{~cm})$ (Eiler et al. 2003; Boros et al. 2017).

The key primary producers in soda lakes of the Carpathian Basin are cyanobacteria, eukaryotic green algae and euglenophytes (Vörös et al. 2008; Somogyi et al. 2017). Phytobenthos is considered to be negligible due to the strong underwater light limitation (Boros et al. 2013), while phytoplankton (especially in the turbid-type waters) is usually dominated by pico-sized $(<3 \mu \mathrm{m})$ species (Vörös et al. 2008; Felföldi et al. 2009; Somogyi et al. 2009, 2017) and has characteristic seasonal changes. Below $15{ }^{\circ} \mathrm{C}$, picoeukaryotes (mainly Chloroparva and Choricystis) dominate, while above this temperature picocyanobacteria (mostly Synechococcus/Cyanobium) occur (Vörös et al. 2008; Felföldi et al. 2009, 2011; Somogyi et al. 2009, 2011, 2016). Interestingly, pico-sized green algae regularly bloom under the ice during winter (Somogyi et al. 2009; Pálffy et al. 2014); while in spring and summer, blooms of larger (mainly green) algae could be formed due to the high productivity of these waters, which occasionally co-occur with mass production of purple bacteria near the sediment surface (Borsodi et al. 2013).

The aim of the present study was the characterization of a dual bloom, which occurred in a soda pan with a special focus on the bacterial community inhabiting the purple layer. Comparing the obtained results (physicochemical parameters and taxonomic composition) with a similar, previous dual bloom event reported from the studied region (Borsodi et al. 2013), the underlying factors shaping the bacterial community composition (BCC) of these Oocystis-associated purple bacterial blooms were revealed.

\section{Materials and methods}

\section{Study site and sample collection}

An anonymous, small, turbid soda pan (N46 $45.818^{\prime}$, E19 $\left.{ }^{\circ} 10.828^{\prime}\right)$, located in the Kiskunság National Park near Soltszentimre (Hungary, Central Europe), was sampled on 23 April 2014. In their great cadastre, Boros et al. (2013) designated it as anonymous lake no. 60 . Water depth reportedly fluctuates between 0 and $\sim 60 \mathrm{~cm}$; the average water surface is 0.58 ha (Boros et al. 2013). Pan water is dominated by $\mathrm{Na}^{+}$and $\mathrm{HCO}_{3}^{-}>\mathrm{Cl}^{-}$(Table 1, Supplementary Figure 1), which is supplied mainly by groundwater and precipitation (Simon et al. 2011), and neither has vegetation cover nor surface inflow or outflow (Boros et al. 2013).

A cylinder was used for sample collection, and subsamples were taken from the upper, green-colored water and from the purple layer over the sediment using a pipette. Determination of the BCC was carried out only from the latter.

\section{Limnological and water chemistry analyses}

Basic physicochemical parameters were determined on site using a MultiLine P 8211 multimeter (WTW). Chemical analyses were performed under laboratory conditions according to the methods described in detail in Felföldi et al. (2016).

Table 1 Basic characteristics of the studied anonymous soda pan water and measured physicochemical parameters during the dual bloom Previous data (2009 and 2010) were taken from Boros et al. (2013)

\begin{tabular}{|c|c|c|c|}
\hline Parameters & 17 May 2009 & 6 March 2010 & 23 April 2014 \\
\hline Depth $(\mathrm{cm})$ & 5 & 58 & 5 \\
\hline $\mathrm{pH}$ & 9.47 & 9.02 & 10.16 \\
\hline Conductivity (mS/cm) & 33.0 & 4.8 & 15.5 \\
\hline $\mathrm{O}_{2}$ conc. $(\mathrm{mg} / \mathrm{L})$ & 13.4 & 14.3 & n.d. \\
\hline Pt color $(\mathrm{mg} / \mathrm{L})$ & 516 & n.d. & n.d. \\
\hline Turbidity (NTU) & n.d. & n.d. & 490 \\
\hline TSS (mg/L) & 1307 & 76.7 & n.d. \\
\hline $\mathrm{K}^{+}(\mathrm{mg} / \mathrm{L})$ & 7.6 & n.d. & n.d. \\
\hline $\mathrm{Na}^{+}(\mathrm{mg} / \mathrm{L})$ & 1145 & n.d. & n.d. \\
\hline $\mathrm{Ca}^{2+}(\mathrm{mg} / \mathrm{L})$ & 7.4 & n.d. & n.d. \\
\hline $\mathrm{Mg}^{2+}(\mathrm{mg} / \mathrm{L})$ & 9.3 & n.d. & n.d. \\
\hline $\mathrm{SO}_{4}{ }^{2-}(\mathrm{mg} / \mathrm{L})$ & 255 & n.d. & 370 \\
\hline $\mathrm{Cl}^{-}(\mathrm{mg} / \mathrm{L})$ & 592 & n.d. & n.d. \\
\hline $\mathrm{HCO}_{3}^{-}(\mathrm{mg} / \mathrm{L})$ & 1893 & n.d. & n.d. \\
\hline $\mathrm{CO}_{3}^{2-}(\mathrm{mg} / \mathrm{L})$ & 47.0 & n.d. & n.d. \\
\hline $\mathrm{NH}_{4}^{+}-\mathrm{N}(\mathrm{mg} / \mathrm{L})$ & n.d. & n.d. & 19.8 \\
\hline $\mathrm{NO}_{2}{ }^{-}-\mathrm{N}(\mathrm{mg} / \mathrm{L})$ & n.d. & n.d. & $<0.01$ \\
\hline $\mathrm{NO}_{3}{ }^{-}-\mathrm{N}(\mathrm{mg} / \mathrm{L})$ & n.d. & n.d. & 47.0 \\
\hline $\mathrm{TN}(\mathrm{mg}(\mathrm{L})$ & n.d. & n.d. & 135 \\
\hline $\mathrm{SRP}(\mathrm{mg} / \mathrm{L})$ & 2.6 & n.d. & 37 \\
\hline TOC (mg/L) & n.d. & n.d. & 1143 \\
\hline Chl $a(\mathrm{mg} / \mathrm{L})$ & 1.0 & n.d. & $10.6^{\mathrm{a}}$ \\
\hline
\end{tabular}

$N T U$ nephelometric turbidity unit, TN total nitrogen, TOC total organic carbon, SRP soluble reactive phosphorous, n.d. not determined

${ }^{\mathrm{a} D}$ Data represent only the upper, green layer 
For pigment analyses, the samples were filtered through a GF-5 glass fiber filter (Whatman). Chlorophyll $a$ (Chl $a$ ) and bacteriochlorophyll $a$ (Bchl $a$ ) were extracted from the filters as described in Felföldi et al. (2016), while another filter set per se was used for in vivo absorption measurements. Chlorophyll concentration was measured using the method of Wellburn (1994), and the concentration of Bchl $a$ was determined according to Biel (1986). In vivo absorption spectra were recorded with a $160 \mathrm{~A}$ UV-Vis spectrophotometer (Shimadzu) between 380 and $900 \mathrm{~nm}$.

Native preparations from the two layers were photographed using an Olympus BX51 microscope with a CCD camera (Olympus DP71).

\section{Determination of BCC based on total DNA analysis}

Community DNA was extracted according to Szabó et al. (2017). For the determination of BCC, next-generation DNA sequencing (NGS) was applied using the protocol and sequence analysis pipeline as described previously (Szabó et al. 2017). For this, the V3-V4 region of the $16 \mathrm{~S}$ rRNA gene was amplified with S-D-Bact-0341-b-S-17 forward (5'-CCTACGGGNGGCWGCAG-3') and S-D-Bact-0785a-A-21 reverse (5'-GACTACHVGGGTATCTAATCC-3') primers (Klindworth et al. 2013). Based on the proposed species-level sequence similarity threshold (Tindall et al. 2010), operational taxonomic units (OTUs) were picked at 97\% similarity. Raw sequence data are available under the NCBI BioSample ID SAMN10724752. Sequences of cultivated strains (see below), and those (strains and clones) from the purple bacterial bloom published in Borsodi et al. (2013) were also analyzed using the same pipeline. Since plastid 16S rRNA gene references are underrepresented in the ARB-SILVA database, chloroplast sequences were analyzed separately as described in detail by Kalwasińska et al. (2017).

The ratio of Archaea and Bacteria was determined with qPCR targeting the 16S rRNA gene. All reactions were carried out in triplicates in a StepOnePlus Real-Time PCR System (Thermo Fisher Scientific) using TaqMan Gene Expression Master Mix (Thermo Fisher Scientific). A final volume of $16 \mu \mathrm{L}$ was applied with $1 \times$ Taqman Gene Expression Master Mix and $1 \mu \mathrm{L}$ DNA sample. In case of the Bacteria-specific reaction, the following primers and probe were applied: $1.2 \mu \mathrm{M}$ BACT1369F (5'-CGGTGAATA CGTTCYCGG-3'), $1.0 \mu \mathrm{M}$ PROK1492R (5'-GGWTACCTT GTTACGACTT-3'), $0.5 \mu \mathrm{M}$ TM1389F (5'-FAM-CTTGTA CACACCGCCCGTC-BHQ-3') (Suzuki et al. 2000); while for Archaea, $0.8 \mu \mathrm{M}$ Arch349F (5'-GYGCASCAGKCGMGAAW-3'), $0.8 \mu \mathrm{M}$ Arch806R (5'-GGACTACVSGGGTAT CTAAT-3') and $0.5 \mu \mathrm{M}$ Arch516F (5'-FAM-TGYCAGCCG CCGCGGTAAHACCVGC-BHQ-3') primers and specific probe were used (Takai and Horikoshi 2000). Reactions were carried out using the thermal profile: $50{ }^{\circ} \mathrm{C}$ for $2 \mathrm{~min}$, $95{ }^{\circ} \mathrm{C}$ for $10 \mathrm{~min}$, followed by 40 cycles at $95^{\circ} \mathrm{C}$ for $15 \mathrm{~s}$ and $60 \mathrm{~s}$ at $56{ }^{\circ} \mathrm{C}$ for the Bacteria- and at $59{ }^{\circ} \mathrm{C}$ for the Archaeaspecific reaction. Standard curves were used for the estimation of 16S rRNA gene numbers using the StepOne v2.3 software (Thermo Fisher Scientific) based on serial tenfold dilution $\left(10^{9}-10^{3}\right.$ copy) of genomic DNA from Nitrincola lacisaponensis DSM $16316^{\mathrm{T}}$ and Thermoplasma acidopilum DSM $1728^{\mathrm{T}}$. Gene copy numbers were determined based on the molar mass values of the standard amplicons.

\section{Analyses based on bacterial strain cultivation}

For cultivation of bacteria, three different media were used: 'R' [DSMZ medium 830 (R2A; see details: http://dsmz. de), pH 10, adjusted with $1 \mathrm{M} \mathrm{NaOH}]$, ' $\mathrm{C}$ ' [1 L autoclaved sample water, $16 \mathrm{~g}$ gellan gum (Gelzan CM, Sigma), $0.6 \mathrm{~g}$ $\mathrm{MgSO}_{4} \times 7 \mathrm{H}_{2} \mathrm{O}$ and $\left.\left.0.3 \mathrm{~g} \mathrm{CaCl}_{2} \times 2 \mathrm{H}_{2} \mathrm{O}\right)\right]$ and ' $\mathrm{S}$ ' $\left(1 \mathrm{~L} \mathrm{dH}_{2} \mathrm{O}\right.$, $16 \mathrm{~g}$ gellan gum, $1 \mathrm{~g}$ yeast extract, $0.6 \mathrm{~g} \mathrm{MgSO}_{4} \times 7 \mathrm{H}_{2} \mathrm{O}$,

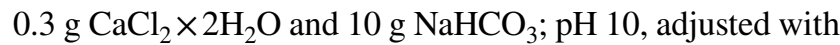
$1 \mathrm{M} \mathrm{NaOH}$ ). A tenfold dilution series using sterile distilled water was prepared from the sample, and aliquots were subsequently spread onto solid media. Incubations were carried out under both aerobic and anaerobic (Microbiology Anaerocult ${ }^{\circledR}$ A mini, Merck) conditions at room temperature under scattered light. Colony counts were recorded after 19 days, then randomly picked colonies were isolated and purified; the obtained strains were used for downstream analyses (the first letter of the stain codes is according to the applied media).

DNA was extracted from bacterial strains with the G-spin ${ }^{\text {TM }}$ Total DNA Extraction Kit (iNtRON Biotechnology). The 16S rRNA gene was amplified by PCR using the primers 27F (Lane 1991) and 1492R (Polz and Cavanaugh 1998). PCR products were purified and sequenced by LGC Genomics (Berlin, Germany). Chromatograms were manually corrected with Chromas (Technelysium). For taxonomic identification, EzBioCloud's online service was used (Yoon et al. 2017). Sequences were screened for chimeras using Pintail 1.0 (Ashelford et al. 2005). GenBank accession numbers of the obtained sequences are: KR233183-KR233245.

Measuring the $\mathrm{Bchl}$ concentration using the spectroscopy-based method of Biel (1986) was not possible due to the weak growth rate of strains which yielded low amount of biomass. Therefore, microscopy- and PCR-based techniques were applied to assess the phototrophic potential of the strains. Briefly, the cells were detected with an Olympus BX51 epifluorescence microscope upon excitation at 350-550 nm (excitation of Bchl $a$ ) using a 780-nm high-pass filter and a monochrome CCD (Olympus XM10) camera according to Jiao et al. (2006). All strains were checked for the presence of the pufM gene (coding the $\mathrm{M}$ subunit of the heterodimeric cores of the photosynthetic reaction center 
complex) with PCR using the primers pufM_uniFfresh and pufM_uniRfresh (Martinez-Garcia et al. 2012). The $25 \mu \mathrm{L}$ reaction volume contained $1 \times$ Taq buffer (Fermentas), $2 \mathrm{mM}$ $\mathrm{MgCl}_{2}, 0.2 \mathrm{mM}$ dNTP, $0.325 \mu \mathrm{M}$ of each primer, $1 \mathrm{U} \mathrm{Taq}$ polymerase (Fermentas), $10 \mu \mathrm{g}$ BSA (Fermentas) and $1 \mu \mathrm{L}$ DNA. Cycling conditions were as given by Martinez-Garcia et al. (2012). Amplicons were sequenced and processed as described above. GenBank accession numbers of the obtained sequences are: KX361312-KX361323.

\section{Results}

\section{Results of limnological analyses}

At the time of sampling, $\mathrm{pH} 10.2$ and $15.5 \mathrm{mS} / \mathrm{cm}$ conductivity were measured (Table 1), which is equivalent to $12.4 \mathrm{~g} / \mathrm{L}$ salinity according to the conversion coefficient determined for these pans by Boros et al. (2014). Other measured parameters of lake water are shown in Table 1. High levels of total organic carbon (TOC), nitrogen forms, orthophosphate and sulfate were present. The upper layer of the water contained $10.6 \mathrm{mg} / \mathrm{L} \mathrm{Chl} a$ and $1.9 \mathrm{mg} / \mathrm{L} \mathrm{Bchl} a$, while the lower contained $4.0 \mathrm{mg} / \mathrm{L} \mathrm{Chl} a$ and $7.8 \mathrm{mg} / \mathrm{L} \mathrm{Bchl}$ a. Oocystis submarina Lagerheim, a unicellular green alga, was identified microscopically as the sole organism causing the algal bloom (Supplementary Figure S2). Based on microscopy, high density of vibrio-shaped bacteria was observed in the bottom layer. These bacteria showed phototaxis and sulfur globules were also observed (Supplementary Figure S3).

\section{Results of cultivation-based analyses}

The three media used for the determination of heterotrophic bacterial viable cell counts in the purple layer resulted in different plate counts. Under aerobic conditions $1.7 \times 10^{6}, 2.8 \times 10^{7}$ and $3.5 \times 10^{7} \mathrm{CFU}$ (colony forming units $) / \mathrm{mL}$ were recorded after 19 days of incubation on medium ' $C$ ', ' $R$ ' and ' $S$ ', respectively. Anaerobic cultivation yielded lower or similar values: $4.2 \times 10^{4}$ and $3.6 \times 10^{7} \mathrm{CFU} / \mathrm{mL}$ were obtained after 19 days in the case of media ' $\mathrm{C}$ ' and ' $\mathrm{S}$ ', respectively, while no colony formation was observed using medium ' $R$ '. Therefore, medium ' $S$ ' was the most suitable for the growth of facultative anaerobic bacteria present in the sample.

From the three different solid media, 63 pure cultures were obtained, 51 with aerobic, 12 with anaerobic cultivation: 6 and 4 strains from medium ' $C$ ', 17 and 8 strains from medium ' $S$ ', 28 from ' $R$ ' agar plates, respectively. According to their 16S rDNA sequences, 37 strains belonged to phylum Proteobacteria (Alphaproteobacteria, 17 and Gammaproteobacteria, 20) and 26 strains to Bacteroidetes (Fig. 1). Isolates showed $89.0-100 \%$ sequence similarity values with type strains of validly published species (Table 2). No clear selectivity of the media was observed, while anaerobic cultivation resulted in similar bacteria as the aerobic one (e.g. Halomonas, Porphyrobacter, Roseicitreum), only few taxa were isolated exclusively under anaerobic conditions (represented by three strains showing the highest $16 \mathrm{~S}$ rRNA gene similarities to Erythromicrobium, Ectothiorhodospira and Adhaeribacter type strains).

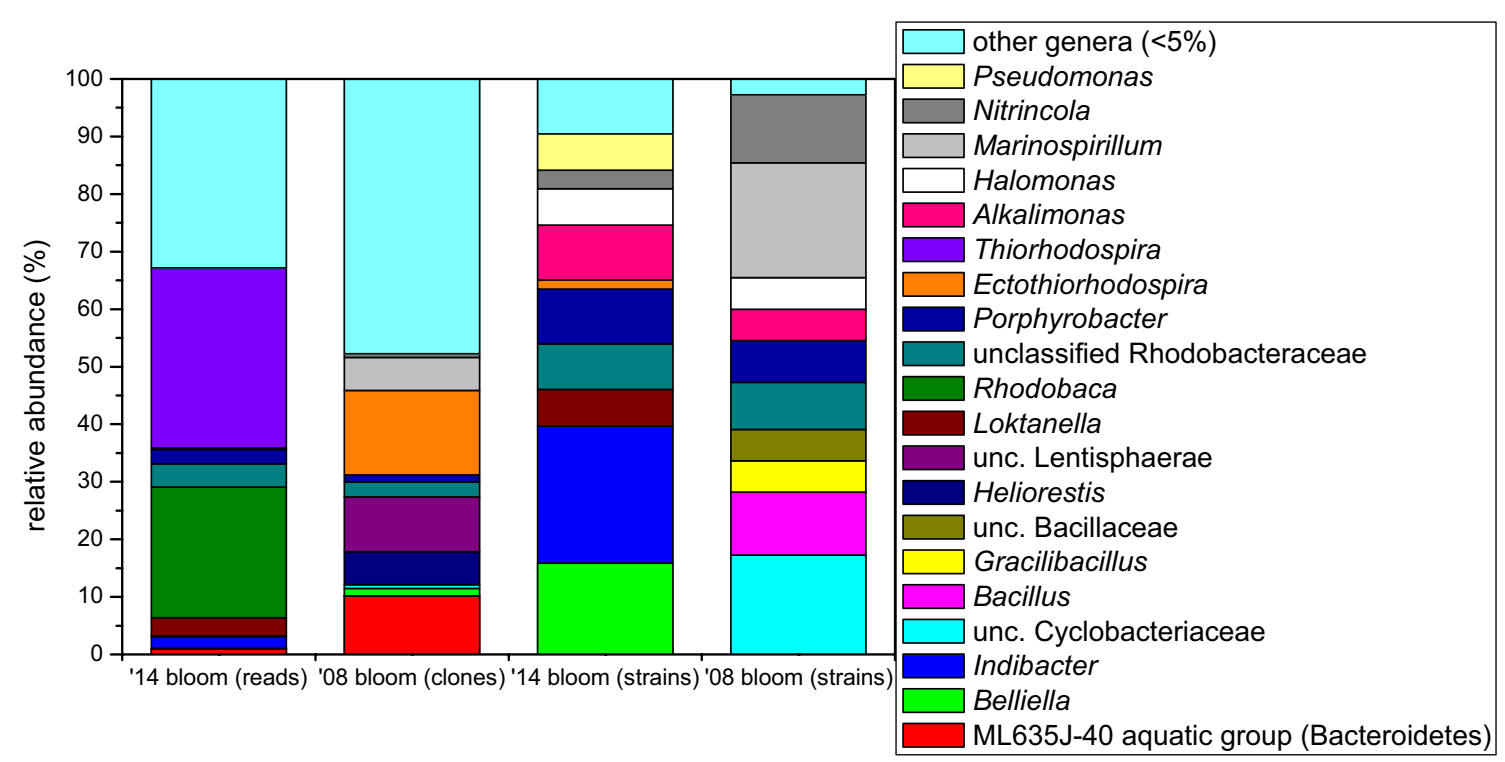

Fig. 1 BCC of purple layer at genus level from Böddi-szék in 2008 (re-analysis of data published in Borsodi et al. 2013) and from an anonymous soda pan near Soltszentimre in 2014 based on different methods (cultivation, cloning and NGS). Only genera or equal ranks of uncultured bacteria with abundance above 5\% are shown. Term 'unc.' stands for 'unclassified' 
Table 2 Taxonomic affiliation of the bacterial strains isolated from the purple layer based on 16S rRNA gene sequence similarity

\begin{tabular}{|c|c|c|c|c|c|c|}
\hline Phylum/Class & Order & Strain code & Closest species & $\begin{array}{l}\text { 16S rRNA } \\
\text { gene similarity } \\
(\%)\end{array}$ & $\begin{array}{l}\text { Presence } \\
\text { of the } \\
\text { pufM } \\
\text { gene }\end{array}$ & $\begin{array}{l}\text { Number of strains } \\
\text { in sequence group }\end{array}$ \\
\hline \multirow{9}{*}{$\begin{array}{l}\text { Proteobacteria } \\
\text { Alphaproteobacteria }\end{array}$} & \multirow[t]{3}{*}{ Sphingomonadales } & S4B-2 & Erythromicrobium ramosum & 98.53 & + & 1 \\
\hline & & S5B-2 & $\begin{array}{l}\text { Porphyrobacter } \\
\text { colymbi/donghaensis }\end{array}$ & 99.17 & - & 1 \\
\hline & & R4-10P & Porphyrobacter neustonensis & 99.05 & $\begin{array}{l}\text { only in } \\
\text { C4B-1 }\end{array}$ & 4 \\
\hline & \multirow[t]{5}{*}{ Rhodobacterales } & S4-11 & Loktanella vestfoldensis ${ }^{a}$ & 99.36 & + & 4 \\
\hline & & R4-14 & Rhodobaca barguzinensis & 97.71 & + & 2 \\
\hline & & S4-16 & Roseinatronobacter monicus & 97.71 & + & 1 \\
\hline & & R3-13B & Roseicitreum antarcticum & 99.58 & + & 2 \\
\hline & & S5-6A & Rhodobaculum claviforme & 99.87 & - & 1 \\
\hline & Rhizobiales & S4-27B & Chelatococcus compost $i$ & 95.24 & - & 1 \\
\hline \multirow[t]{8}{*}{ Gammaproteobacteria } & Chromatiales & C3B-1 & Ectothiorhodospira shaposhnikovii & 100 & + & 1 \\
\hline & Oceanospirillales & R3-4 & Halomonas shengliensis & 98.97 & - & 1 \\
\hline & \multirow[t]{2}{*}{ Oceanospirillales } & S4-1 & Halomonas ventosae & 98.46 & - & 3 \\
\hline & & $\mathrm{R} 4-8^{\mathrm{b}}$ & Nitrincola alkalisediminis & 98.56 & - & 2 \\
\hline & \multirow[t]{2}{*}{ Pseudomonadales } & R3-8 & Pseudomonas salegens & 98.87 & - & 1 \\
\hline & & R4-10 & Pseudomonas salegens & 98.75 & - & 3 \\
\hline & Vibrionales & R4-7 & Vibrio metschnikovii & 99.70 & - & 3 \\
\hline & Alteromonadales & R4-13 & Alkalimonas amylolytica & 99.90 & - & 6 \\
\hline \multirow{4}{*}{$\begin{array}{l}\text { Bacteroidetes } \\
\text { Cytophagia }\end{array}$} & \multirow[t]{2}{*}{ Cytophagales } & S4-3 & Belliella pelovolcani & 99.80 & - & 5 \\
\hline & & R3-1 & Belliella aquatica & 97.28 & - & 5 \\
\hline & Cytophagales & R3-9 & Mongoliibacter ruber & 98.29 & - & 15 \\
\hline & Cytophagales & S4B-3 & Adhaeribacter aerophilus & 88.82 & - & 1 \\
\hline
\end{tabular}

${ }^{\mathrm{a}}$ Loktanella vestfoldensis was recently reclassified as Yoonia vestfoldensis by Wirth and Whitman (2018)

${ }^{\mathrm{b}}$ This phylotype was recently described as N. schmidtii (Borsodi et al. 2017)

Vast majority of alphaproteobacterial strains were red colored (e.g. members of genera Erythromicrobium, Porphyrobacter, Loktanella and Rhodobaculum), four of them produced Bchl (Supplementary Figure S4). One of these strains, Roseinatronobacter sp. S4-16 stopped expressing its pigment(s) during the cultivation process. An anaerobic gammaproteobacterial strain showed $100 \%$ sequence similarity to an alkalophilic purple sulfur bacterium, Ectothiorhodospira shaposhnikovii. Other strains from this class were typical heterotrophs, with high similarities to halophilic or alkalophilic representatives of genera Alkalimonas, Halomonas, Nitrincola, Pseudomonas and Vibrio. All Bacteroidetes strains belonged to order Cytophagales, and were pink or bright red colored. Five strains were closely (99.8\%) related to the type strain of Belliella pelovolcani, while another five strains probably represent a new species within this genus ( $\sim 97 \%$ similarity to type strains). Fifteen strains were affiliated to Mongoliibacter, while strain S4B-3 may represent a new family, as the shared sequence similarity values to type strains were less than $89 \%$.
Strains were screened for the presence of the pufM gene, and amplicons were obtained in the case of 12 strains (19\% of total strains). As in many cases a longer fragment was co-amplified with the deposited amplicon ( $<150 \mathrm{nt}$ length), we presume an upstream, secondary annealing position of the forward (pufM_uniFfresh) primer inside the pufL gene. Taxon identification (against the GenBank database) based on $p u f M$ gene sequences was consistent to the $16 \mathrm{~S}$ rDNAbased results. The pufM-positive strains belonged to the three purple bacterial groups [purple sulfur bacteria (PSB), purple nonsulfur bacteria (PNSB) and aerobic anoxygenic phototrophs (AAP)]. With the exception of the Porphyrobacter strains (one out of five was positive), strains from the same genus were either positive or negative. All pufMcontaining isolates and representatives of sequence groups from $p u f M$-negative strains were investigated with epifluorescence microscopy to detect the presence of Bchl. Not all of the pufM-positive strains were found to synthesize Bchl pigments, but Bchl was not detected in any of the pufM-negative strains. Interestingly, one strain (Roseinatronobacter 
sp. S4-16) stopped producing Bchl pigments during the cultivation process.

\section{Results of cultivation-independent analyses}

Overall, 3398 high-quality sequences were obtained with next-generation DNA sequencing, which were clustered to 162 bacterial OTUs. Two OTUs with 27 sequences were identified as eukaryotic plastid and belonged to the chlorophyte genus Oocystis (unfortunately no $O$. submarina $16 \mathrm{~S}$ rRNA gene sequence is available in GenBank currently; Supplementary Figure S5).

Altogether 18 bacterial phyla were detected (Fig. 2). Proteobacteria was the most abundant phylum, dominated by Alpha- (36.2\% of total bacterial reads) and Gammaproteobacteria $(35.9 \%)$, while only low relative abundance of Deltaproteobacteria was detected (2.9\%), and the contribution of Betaproteobacteria was negligible $(<0.1 \%)$. Other bacterial phyla represented only a minor fraction of the bacterial community: Firmicutes (7.1\%), Verrucomicrobia (6.3\%), Bacteroidetes (5.8\%), etc. (Figure 2). Almost onethird of the sequences was affiliated with the PSB family Ectothiorhodospiraceae (Gammaproteobacteria) and the vast majority of these sequences belonged to a single OTU assigned to the genus Thiorhodospira, while other five OTUs containing two to four sequences clustered into a Thioalkalivibrio, two Ectothiorhodospira and two unclassified groups (Fig. 1). Another third of the reads was affiliated with PNSB and AAP groups of the Rhodobacteraceae family
(Alphaproteobacteria), dominated by a single OTU belonging to genus Rhodobaca, while a Loktanella and a Porphyrobacter OTU turned out to be also significant ( $3 \%$ both). Other notable groups (with $1-4 \%$ relative abundance) were: two unclassified OTUs from each Firmicutes and Alphaproteobacteria; two verrucomicrobial OTUs (from Haloferula and a closely related unclassified genus) and one OTU from genera Desulfonatronum (Deltaproteobacteria), Indibacter (Bacteroidetes) and group ML602 J-51 (Actinobacteria). In total, 11 OTUs showed higher relative abundance than $1 \%$, together they contributed $75.7 \%$ of the bacterial community.

From the 162 bacterial OTUs, 10 were shared between cultivated strains and the NGS library, which included 43 strains (68\% of isolates) and 1221 sequences (36\% of total reads). 20 strains forming seven OTUs were not detected by NGS.

Based on the result of qPCR, the 16S rRNA gene copy number of Archaea was below the detection limit (40 PCR cycles).

\section{Discussion}

\section{Features of the dual bloom}

At the time of sampling, this small pan was close to desiccation with a maximum depth of $5 \mathrm{~cm}$. The low water level resulted in high conductivity, though the salinity value still fell into the hyposaline category according to Hammer's

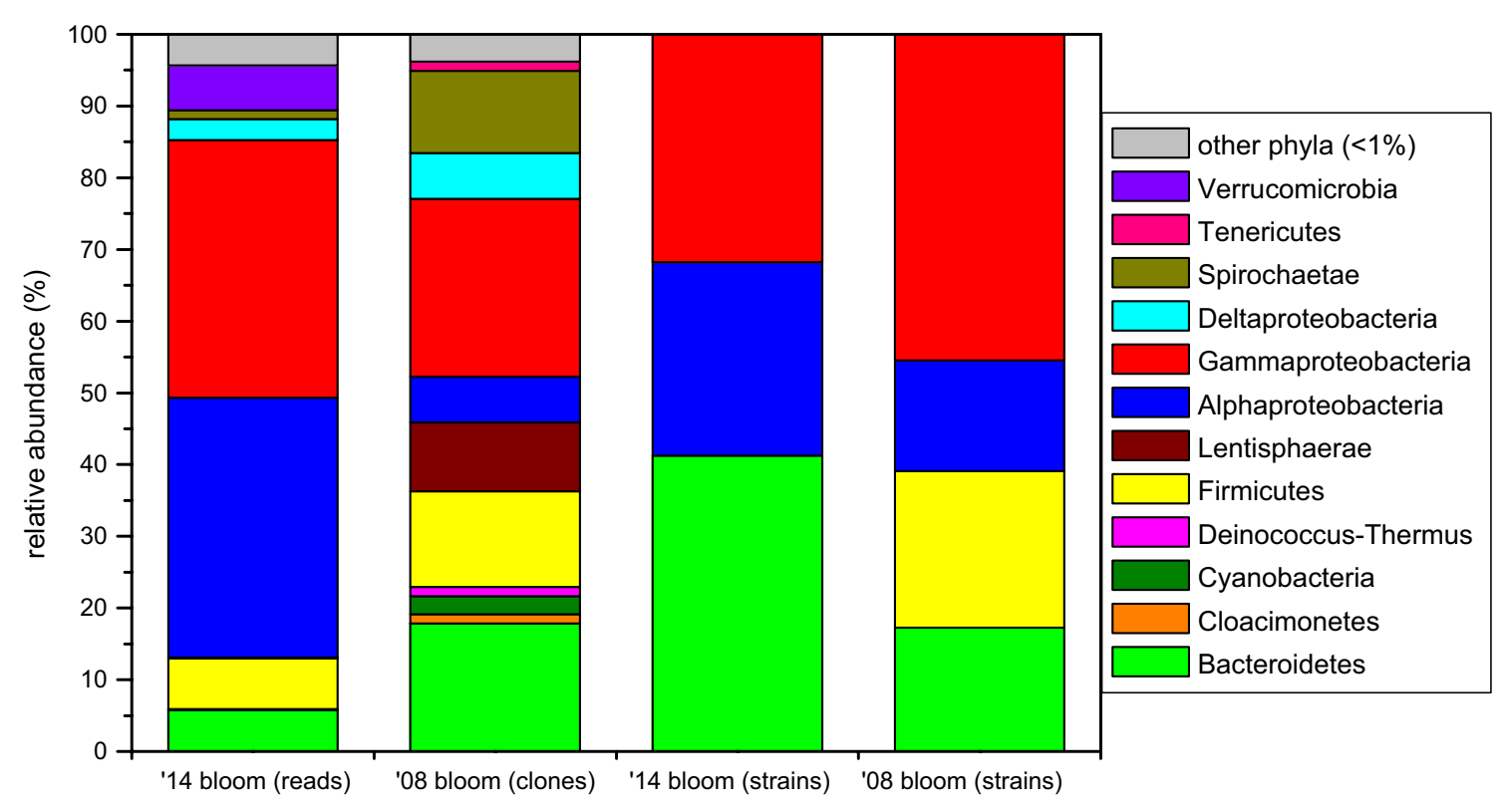

Fig. 2 BCC of purple layer at phylum level from Böddi-szék in 2008 (re-analysis of data published in Borsodi et al. 2013) and from an anonymous soda pan near Soltszentimre in 2014 based on different methods (cultivation, cloning and NGS). Only phyla or classes (in case of Proteobacteria) with abundance above $1 \%$ are shown 
(1986) classification system. Salinity is thought to have a major influence on microbial community composition ( $\mathrm{Wu}$ et al. 2006; Sorokin et al. 2014), exceeding the effect of temperature and pH (Lozupone and Knight 2007). The high levels of TOC and inorganic nutrients (Table 1) suggest no bottom-up limitation, and are originated from the droppings of livestock (buffalo) or migrating aquatic birds (Boros et al. 2008). Therefore, algal blooms occur frequently in shallow soda pans (Somogyi et al. 2009), but the observed dual bloom (simultaneous presence of algae and purple bacteria) is uncommon (Borsodi et al. 2013).

The green layer observed on the surface was virtually a monoculture of the unicellular green alga Oocystis submarina. In general, pico-sized algae dominate the phytoplankton, and $O$. submarina is found to be rare in the soda pans of the Carpathian Basin (Somogyi et al. 2009, 2017; Pálffy et al. 2014), though it bloomed in a neighboring soda pan in 2008 with a purple layer formed beneath (Borsodi et al. 2013). Phytoplankton blooms undergo succession stages including the exudate profiles of the cells. At the developmental phase, low-molecular weight (LMW) compounds (including amino acids with high nitrogen content) dominate, while during the aging, algae release mainly highmolecular weight (HMW) macromolecules (such as polysaccharides, lipids and proteins) (Buchan et al. 2014).

As postulated by Tank et al. (2011), calm, sunny and warm conditions favor PSB blooms. The dense layer of algae hinders mixing and makes favorable light conditions for phototrophic purple bacteria in the deeper layer (Vörös et al. 1998; Stomp et al. 2007). Additionally, as heterotrophs consume all the oxygen, the chemocline rose from the sediment just below the green layer, turning the bottom of the pan anaerobic, being advantageous to the growth of (generally) anaerobic PSB from the Ectothiorhodospiraceae family (Imhoff 2006). Moreover, the proximity of sediment and the activity of sulfate-reducing bacteria provide sulfide for sulfur bacteria. As these habitats are turbid due to wind-induced mixing and groundwater upwelling (Boros et al. 2017) which provide competitive advantage to picoalgae (Somogyi et al. 2017), we assume that besides calm weather, other factors (e.g. other meteorological and hydromorphological conditions, geographical position, selective zooplankton grazing; Eiler et al. 2003; Horváth et al. 2014) had contributed to the development of the Oocystis bloom. Contrary to many saline lakes (e.g. Lake Shira or Lake Shunet; Rogozin et al. 2005), the presence of the purple layer is not permanent, but only an occasional event in the studied region.

\section{Purple bacteria in the purple layer}

In the purple layer, the observed motile vibrios had similar cellular characteristics as the family Ectothiorhodospiraceae (Imhoff 2006). The purple layer was dominated by two
OTUs, a PSB belonging to genus Thiorhodospira and a PNSB from genus Rhodobaca. Although PSB prefer anaerobic or microaerobic conditions (Imhoff, 2006), these bacteria have been reported previously from the proximity of algal blooms or cyanobacterial mats (Kompantseva et al. 2009; Borsodi et al. 2013). Because PSB are considered to have the major role in purple layer formation (Ollivier et al. 1994), we suppose that in this case, members of Thiorhodospira were the main bloom-formers, while other detected red-pigmented taxa (Rhodobaca, Porphyrobacter, Indibacter) found favorable milieu created by the algae or the PSB.

Members of the Ectothiorhodospiraceae family are well known from alkaline aquatic environments (Sorokin et al. 2004; Imhoff, 2006; Vavourakis et al. 2016); additionally, Sorokin et al. (2004) showed moderate halotolerance of isolated Thiorhodospira species. Interestingly, in an earlier blooming event in 2008 in a nearby soda pan (Böddi-szék; Borsodi et al. 2013, Fig. 1), no Thiorhodospira sequences were found, but Ectothiorhodospira was the major PSB component in the purple layer (with $14.6 \%$ relative abundance). However, regarding the bloom observed in 2014, one of the isolates showed $100 \%$ sequence similarity with the type strain of Ectothiorhodospira shaposhnikovii, but based on NGS this was a negligible PSB group in this case.

It should be noted that the second most abundant OTU based on NGS ('Rhodobaca' in Fig. 1) harbored two valid genera, Rhodobaca and Roseinatronobacter, as type strains belonging to these genera share high (98.3-99.0\%) $16 \mathrm{~S}$ rRNA gene sequence similarity values. Another problem of proper taxon assignment was observed in the case of 'unclassified Rhodobacteraceae' (Fig. 1), since bootstrap values of Rhodobaca and related strains did not reach the threshold required for genus-level identification. Order Rhobobacterales [including both PNSBs (e.g. Rhodobaca) and AAPs (e.g. Roseinatronobacter and Loktanella)] occur frequently in soda lakes (Vavourakis et al. 2016; Szabó et al. 2017). This is a metabolically diverse group with the ability to utilize a wide range of substrates (Moran et al. 2007). Several members favor LMW organic matter, including byproducts of algae, and the association of these bacteria with phytoplankton was supported by many studies (e.g. Moran et al. 2007; Buchan et al. 2014). However, Sarmento et al. (2016) studying marine microbial communities found that not the quality but the quantity of organic matter has the major effect on Alphaproteobacteria.

Most of our isolates from this group (in total 12 bacterial strains) contained the pufM gene, which encodes one of the core proteins of the photosynthetic reaction center. The expression of the photosynthetic reaction center genes is considered to be highly dependent on environmental conditions (Jeanthon et al. 2011), which is a possible explanation regarding the lack of $\mathrm{Bchl}$ pigments in strains containing 
the pufM gene besides having an incomplete photosynthetic gene cluster.

\section{Other bacteria in the purple layer}

Several isolated strains represented the major contributors of the bacterial community (Rhodobaca, Loktanella, Porphyrobacter and Indibacter), while others represented potentially new taxa (one of these has been described as a new species recently, Nitrincola schmidtii; Borsodi et al. 2017). This could be the result of the high nutrient and organic matter content of the sample and the application of newly designed media. The complete absence of certain isolated heterotrophic genera (Alkalimonas, Halomonas, Nitrincola, Pseudomonas and Vibrio) from the NGS amplicon library can be explained by their relatively low abundance and easy cultivability. On the other hand, a few highly similar sequences to these strains were obtained from other soda lakes in this region (Szabó et al. 2017), and these genera were among the first cultivated bacteria from soda lakes (Grant and Sorokin 2011).

In our study, relatively few groups dominated the bacterial community (two OTUs from genera Thiorhodospira and Rhodobaca proportionated 55\% of the obtained NGS reads, representatives of Gammaproteobacteria and Alphaproteobacteria, respectively). Our earlier investigations on nearby soda pans (Szabó et al. 2017; Szabó A., Korponai K., and Felföldi T., unpublished results) showed that Actinobacteria is the most abundant phylum along with Bacteriodetes and class Alphaproteobacteria. All these results support that dynamic changes of environmental parameters at these sites (Kirschner et al. 2002; Felföldi et al. 2009; Somogyi et al. 2009; Boros et al. 2017) induce drastic changes in the composition of planktonic prokaryotes (including occasional blooms).

The different oxygen tolerance of genera detected in the purple layer (Loktanella and Indibacter are obligate aerobic, Thiorhodospira and Desulfonatronum are obligate anaerobes, while Rhodobaca can switch from one to another using different electron acceptors; Koblížek 2015) suggests that an aerobic-anaerobic gradient was present within this $2-\mathrm{cm}-$ thick layer. Desulfonatronum is the most widely reported sulfate-reducing bacterial genus from soda lakes (Sorokin et al. 2011), which supports the electron donor (sulfide) to PSB and PSNB.

Bacteroidetes species have a major role in organic matter biodegradation with the preference of complex, recalcitrant (HMW) molecules (Cottrell and Kirchman 2000; Pérez and Sommaruga 2006). While most of the detected Bacteroidetes bacteria are considered to be obligate aerobes (e.g. Indibacter, Belliella, Aquiflexum), members of the probably anaerobic ML635 J-40 aquatic group (eight OTUs with 9.8\% relative abundance altogether) (Humayoun et al. 2003) was also identified. We suppose that aerobic Bacteroidetes bacteria were associated with algae; their presence in the deeper zone can be explained by gravitational sinking from the green layer.

The dominant Actinobacteria OTU (ML602 J-51) was found to be an infrequent member of the otherwise prevalent phylum in the Central European soda pans (Szabó et al. 2017, Szabó A., Korponai K. and Felföldi T., unpublished results). Phylum Verrucomicrobia (e.g. Haloferula) have been reportedly found to be associated with blooming events (Eiler and Bertilsson 2004), and members of this phylum could contribute with $2-10 \%$ to soda pan bacterial communities (Szabó et al. 2017; this study).

Comparing to other soda lake studies (Grant 2006; Antony et al. 2013; Borsodi et al. 2013), the complete absence of Bacillus and related species in our isolates and NGS reads is striking, though the applied method is suitable to their identification (Kalwasińska et al. 2017). Most of the detected Firmicutes sequences (66\%) fell into a yet uncultured genus of order Clostridiales, while the phylum itself seems to be negligible (7\%), though this value exceeds our previous findings (0.2-1.5\%) (Szabó et al. 2017).

The negligible proportion of Archaea can be a result of the relatively low salinity (between 3.8 and $24.6 \mathrm{~g} / \mathrm{L}$; Table 1) of the pan (Oren 1994).

\section{Dual blooms in the region}

Comparing the revealed $\mathrm{BCC}$ in this anonymous soda pan with a previous Oocystis-associated purple bacterial bloom in a neighboring soda lake (Böddi-szék), significant differences were found (Figs. 1 and 2). While both communities were dominated by PSB, different genera were identified. Other, functionally similar groups also showed habitat separation: Belliella was present in the previous, while in the former blooming event it was replaced by its close relative Indibacter. Rhodobaca was absent and other alphaproteobacteria composed only a minor fraction in Böddi-szék, where a yet uncultured Bacteroidia group (ML635 J-40 aquatic group) showed higher relative abundance. Some important groups in the BCC of Böddi-szék, such as heliobacteria, Lentisphaerae, and heterotrophic gammaproteobacteria were absent in the community of the anonymous soda pan. On the contrary, Loktanella was present only in the latter. The re-analysis of the originally published data (Borsodi et al. 2013) enabled us to compare the two datasets generated through different methods. It is also noteworthy, that in the re-analyzed dataset many taxa were assigned to different genera than originally, which highlights the need to avoid outdated taxonomy, and the fact, that the field of soda lake research is still thriving.

It seems that temperature (Kirschner et al. 2002) could be the key selection factor for PSB, not only in the Chromaticeae 
(Tank et al. 2011) but in the Ectothiorhodospiraceae family as well, since water temperature was higher in the case of Böddi-szék ( $33{ }^{\circ} \mathrm{C}$; Borsodi et al. 2013) than in the case of the anonymous soda pan $\left(23{ }^{\circ} \mathrm{C}\right)$ bloom, and the growth temperature optimum of Ectothiorhodospira strains is usually above, while for Thiorhodospira is below $30^{\circ} \mathrm{C}$ (Oren 2014). Another explanation could be the different ionic compositions of the two lakes, since Böddi-szék is a 'soda-saline' type $\left(\mathrm{Na}^{+}\right.$, $\mathrm{Cl}^{-}>\mathrm{HCO}_{3}{ }^{-}$), while the anonymous pan belongs to the 'soda' type $\left(\mathrm{Na}^{+}, \mathrm{HCO}_{3}{ }^{-}>\mathrm{Cl}^{-}\right)$according to the classification of Boros and Kolpakova (2018).

\section{Summary}

A dual bloom of green algae and purple bacteria in a Central European soda pan was characterized in this study. While algal blooms are common in these waters, the presence of a purple layer is only an occasional event in the studied region. The high level of oxygen produced by the algae was consumed by heterotrophic bacteria in a few centimeters, and a sulfuretum was developed, where sulfate reducers created hydrogen sulfide, which was oxidized to sulfate by PSBs, PNSBs and AAPs. Probably the warm, calm and sunny conditions enabled both the Oocystis bloom, and the development of a sulfuretum in the water as the chemocline rose into the water column from the sediment-water boundary. These special conditions resulted in an uncommon microbial community, dominated by PSB (Thiorhodospira) and PNSB (Rhodobaca) that oxidize sulfide under anaerobic conditions. The purple layer development was probably initiated by the sulfide genesis of sulfatereducing bacteria (Desulfonatronum).

It can be concluded that such purple layer formation in a shallow lake is a result of the combination of several biotic and abiotic factors (e.g. favorable light climate, ionic composition, calm weather, sediment proximity).

Acknowledgements Open access funding provided by Eötvös Loránd University (ELTE). The authors are thankful to Anikó Lajosné Balogh, Nóra Tugyi and Balázs Németh for their technical assistance and to József Kukolya and Erzsébet Baka for providing DNA reference samples. We are also grateful to the anonymous reviewers, who played a significant role in improving the manuscript.

Funding This work was supported by the Hungarian Scientific Research Fund (PD 105407 and PD 112449). Purchase of equipment was financed by the National Development Agency (Grants KMOP4.2.1/B-10-2011-0002 and TÁMOP-4.2.2/B-10/1-2010-0030).

Open Access This article is distributed under the terms of the Creative Commons Attribution 4.0 International License (http://creativeco mmons.org/licenses/by/4.0/), which permits unrestricted use, distribution, and reproduction in any medium, provided you give appropriate credit to the original author(s) and the source, provide a link to the Creative Commons license, and indicate if changes were made.

\section{References}

Antony CP, Kumaresan D, Hunger S, Drake HL, Murrell JC, Shouche YS (2013) Microbiology of Lonar Lake and other soda lakes. ISME J 7:468-476

Ashelford KE, Chuzhanova NA, Fry JC, Jones AJ, Weightman AJ (2005) At least 1 in 20 16S rRNA sequence records currently held in public repositories is estimated to contain substantial anomalies. Appl Environ Microbiol 71:7724-7736

Biel AJ (1986) Control of bacteriochlorophyll accumulation by light in Rhodobacter capsulatus. J Bacteriol 168:655-659

Boros E, Kolpakova M (2018) A review of the defining chemical properties of soda lakes and pans: an assessment on a large geographic scale of Eurasian inland saline surface waters. PLoS One 13:e0202205

Boros E, Nagy T, Pigniczki Cs, Kotymán L, Balogh KV, Vörös L (2008) The effect of aquatic birds on the nutrient load and water quality of soda pans in Hungary. Acta Zool Acad Sci Hung $54: 207-224$

Boros E, Ecsedi Z, Oláh J (eds) (2013) Ecology and management of soda pans in the Carpathian Basin. Hortobágy Environmental Association, Balmazújváros

Boros E, Horváth Zs, Wolfram G, Vörös L (2014) Salinity and ionic composition of the shallow astatic soda pans in the Carpathian Basin. Ann Limnol Intern J Limnol 50:59-69

Boros E, V-Balogh K, Vörös L, Horváth Zs (2017) Multiple extreme environmental conditions of intermittent soda pans in the Carpathian Basin (Central Europe). Limnologica 62:38-46

Borsodi AK, Knáb M, Czeibert K, Márialigeti K, Vörös L, Somogyi B (2013) Planktonic bacterial community composition of an extremely shallow soda pond during a phytoplankton bloom revealed by cultivation and molecular cloning. Extremophiles 17:575-584

Borsodi AK, Korponai K, Schumann P, Spröer C, Felföldi T, Márialigeti K, Szili-Kovács T, Tóth E (2017) Nitrincola alkalilacustris sp. nov. and Nitrincola schmidtii sp. nov. novel alkaliphilic bacteria isolated from soda pans and emended description of the genus Nitrincola. Int J Syst Evol Microbiol 67:5159-5164

Buchan A, LeCleir GR, Gulvik CA, González JM (2014) Master recyclers: features and functions of bacteria associated with phytoplankton blooms. Nat Rev Microbiol 12:686-698

Cottrell MT, Kirchman DL (2000) Natural assemblages of marine proteobacteria and members of the Cytophaga-Flavobacter cluster consuming low-and high-molecular-weight dissolved organic matter. Appl Environ Microbiol 66:1692-1697

Eiler A, Bertilsson S (2004) Composition of freshwater bacterial communities associated with cyanobacterial blooms in four Swedish lakes. Environ Microbiol 6:1228-1243

Eiler A, Farnleitner AH, Zechmeister TC, Herzig A, Hurban C, Wesner W, Krachler R, Velimirov B, Kirschner AK (2003) Factors controlling extremely productive heterotrophic bacterial communities in shallow soda pools. Microb Ecol 46:43-54

Felföldi T, Somogyi B, Márialigeti K, Vörös L (2009) Characterization of photoautotrophic picoplankton assemblages in turbid, alkaline lakes of the Carpathian Basin (Central Europe). J Limnol 68:385-395

Felföldi T, Somogyi B, Márialigeti K, Vörös L (2011) Notes on the biogeography of non-marine planktonic picocyanobacteria: reevaluating novelty. J Plankton Res 33:1622-1626

Felföldi T, Ramganesh S, Somogyi B, Krett G, Jurecska L, Szabó A, Vörös L, Márialigeti K, Máthé I (2016) Winter planktonic microbial communities in highland aquatic habitats. Geomicrobiol J $33: 494-504$ 
Grant WD (2006) Alkaline environments and biodiversity. In: Gerday C, Glansdorff N (eds) Extremophiles (life under extreme environmental conditions). Eolss Publishers, Oxford, pp 1-19

Grant WD, Sorokin DY (2011) Distribution and diversity of soda lake alkaliphiles. In: Horikoshi K, Antranikian G, Bull AT, Robb FT, Stetter KO (eds) Extremophiles handbook. Springer, Tokyo, pp $27-54$

Hammer UT (1986) Saline lake ecosystems of the world. Dr W. Junk Publishers, Dordrecht

Horváth Zs, Vad CsF, Tóth A, Zsuga K, Boros E, Vörös L, Ptacnik R (2014) Opposing patterns of zooplankton diversity and functioning along a natural stress gradient: when the going gets tough, the tough get going. Oikos 123:461-471

Humayoun SB, Bano N, Hollibaugh JT (2003) Depth distribution of microbial diversity in Mono Lake, a meromictic soda lake in California. Appl Environ Microbiol 69:1030-1042

Imhoff JF (2006) The family Ectothiorhodospiraceae. In: Dworkin M, Falkow S, Rosenberg E, Schleifer K-H, Stackebrandt E (eds) The prokaryotes. Springer, New York, pp 874-886

Jeanthon C, Boeuf D, Dahan O, Gall FL, Garczarek L, Bendif EM, Lehours AC (2011) Diversity of cultivated and metabolically active aerobic anoxygenic phototrophic bacteria along an oligotrophic gradient in the Mediterranean Sea. Biogeosciences 8:1955-1970

Jiao N, Zhang Y, Chen Y (2006) Time series observation based InfraRed Epifluorescence Microscopic (TIREM) approach for accurate enumeration of bacteriochlorophyll-containing microbes in marine environments. J Microbiol Methods 65:442-452

Kalwasińska A, Felföldi T, Szabó A, Deja-Sikora E, Kosobucki P, Walczak M (2017) Microbial communities associated with the anthropogenic, highly alkaline environment of a saline soda lime, Poland. Antonie Van Leeuwenhoek 110:945-962

Kirschner AK, Eiler A, Zechmeister TC, Velimirov B, Herzig A, Mach R, Farnleitner AH (2002) Extremely productive microbial communities in shallow saline pools respond immediately to changing meteorological conditions. Environ Microbiol 4:546-555

Klindworth A, Pruesse E, Schweer T et al (2013) Evaluation of general 16 S ribosomal RNA gene PCR primers for classical and nextgeneration sequencing-based diversity studies. Nucleic Acids Res 41:e1

Koblížek M (2015) Ecology of aerobic anoxygenic phototrophs in aquatic environments. FEMS Microbiol Rev 39:854-870

Kompantseva EI, Komova AV, Rusanov II, Pimenov NV, Sorokin DY (2009) Primary production of organic matter and phototrophic communities in the soda lakes of the Kulunda steppe (Altai krai). Microbiology 78:643-649

Lane DJ (1991) 16S/23S rRNA sequencing. In: Stackebrandt E, Goodfellow M (eds) Nucleic acid techniques in bacterial systematics. Wiley, New York, pp 115-175

Lozupone CA, Knight R (2007) Global patterns in bacterial diversity. Proc Natl Acad Sci 104:11436-11440

Martinez-Garcia M, Swan BK, Poulton NJ, Gomez ML, Masland D, Sieracki ME, Stepanauskas R (2012) High-throughput single-cell sequencing identifies photoheterotrophs and chemoautotrophs in freshwater bacterioplankton. ISME J 6:113-123

Moran MA, Belas R, Schell MA, González JM, Sun F, Sun S, Binder BJ, Edmonds J, Ye W, Orcutt B, Howard EC, Meile C, Palefsky W, Goesmann A, Ren Q, Paulsen I, Ulrich LE, Thompson LS, Saunders E, Buchan A (2007) Ecological genomics of marine roseobacters. Appl Environ Microbiol 70:4559-4569

Ollivier B, Caumette P, Garcia JL, Mah RA (1994) Anaerobic bacteria from hypersaline environments. Microbiol Rev 58:27-38

Oren A (1994) The ecology of the extremely halophilic archaea. FEMS Microbiol Rev 13:415-439
Oren A (2014) The family Ectothiorhodospiraceae. In: Rosenberg E, DeLong EF, Loy S, Stackebrandt E, Thompson F (eds) The prokaryotes. Springer, Berlin, pp 199-222

Pálffy K, Felföldi T, Mentes A, Horváth H, Márialigeti K, Boros E, Vörös L, Somogyi B (2014) Unique picoeukaryotic algal community under multiple environmental stress conditions in a shallow, alkaline pan. Extremophiles 18:111-119

Pérez MT, Sommaruga R (2006) Differential effect of algal- and soilderived dissolved organic matter on alpine lake bacterial community composition and activity. Limnol Oceanogr 51:2527-2537

Polz MF, Cavanaugh CM (1998) Bias in template-to-product ratios in multitemplate PCR. Appl Environ Microbiol 64:3724-3730

Rogozin DY, Pimenov NV, Kosolapov DB, Chan'kovskaya YV, Degermendzhy AG (2005) Thin-layer vertical distributions of purple sulfur bacteria in chemocline zones of meromictic lakes Shira and Shunet (Khakassia). Dokl Biol Sci 400:54-56

Sarmento H, Morana C, Gasol JM (2016) Bacterioplankton niche partitioning in the use of phytoplankton-derived dissolved organic carbon: quantity is more important than quality. ISME J 10:2582-2592

Simon SZ, Mádl-Szônyi J, Müller I, Gy Pogácsás (2011) Conceptual model for surface salinization in an overpressured and a superimposed gravity-flow field, Lake Kelemenszék area, Hungary. Hydrogeol J 19:701-717

Somogyi B, Felföldi T, Vanyovszki J, Ágyi Á, Márialigeti K, Vörös L (2009) Winter bloom of picoeukaryotes in Hungarian shallow turbid soda pans and the role of light and temperature. Aquat Ecol 43:735-744

Somogyi B, Felföldi T, Solymosi K, Makk J, Homonnay ZG, Horváth $\mathrm{Gy}$, Turcsi E, Böddi $\mathrm{B}$, Márialigeti K, Vörös L (2011) Chloroparva pannonica gen. et sp. nov. (Trebouxiophyceae, Chlorophyta) - a new picoplanktonic green alga from a turbid, shallow soda pan. Phycologia 50:1-10

Somogyi B, Felföldi T, Balogh KV, Boros E, Pálffy K, Vörös L (2016) The role and composition of winter picoeukaryotic assemblages in shallow Central European great lakes. J Gt Lakes Res 42:1420-1431

Somogyi B, Pálffy K, Balogh KV, Botta-Dukát Z, Vörös L (2017) Unusual behaviour of phototrophic picoplankton in turbid waters. PLoS One 12:e0174316

Sorokin DY, Gorlenko VM, Namsaraev BB, Namsaraev ZB, Lysenko AM, Eshinimaev BT, Khmelenina VN, Trotsenko YA, Kuenen JG (2004) Prokaryotic communities of the north-eastern Mongolian soda lakes. Hydrobiologia 522:235-248

Sorokin DY, Kuenen JG, Muyzer G (2011) The microbial sulfur cycle at extremely haloalkaline conditions of soda lakes. Front Microbiol 2:44

Sorokin DY, Berben T, Melton ED, Overmars L, Vavourakis CD, Muyzer G (2014) Microbial diversity and biogeochemical cycling in soda lakes. Extremophiles 18:791-809

Stomp M, Huisman J, Stal LJ, Matthijs HC (2007) Colorful niches of phototrophic microorganisms shaped by vibrations of the water molecule. ISME J 1:271

Suzuki MT, Taylor LT, DeLong EF (2000) Quantitative analysis of small-subunit rRNA genes in mixed microbial populations via 5'-nuclease assays. Appl Environ Microbiol 66:4605-4614

Szabó A, Korponai K, Kerepesi Cs, Somogyi B, Vörös L, Bartha D, Márialigeti K, Felföldi T (2017) Soda pans of the Pannonian steppe harbor unique bacterial communities adapted to multiple extreme conditions. Extremophiles 21:639-649

Takai K, Horikoshi K (2000) Rapid detection and quantification of members of the archaeal community by quantitative PCR using fluorogenic probes. Appl Environ Microbiol 66:5066-5072

Tank M, Blümel M, Imhoff JF (2011) Communities of purple sulfur bacteria in a Baltic Sea coastal lagoon analyzed by pufLM gene libraries and the impact of temperature and $\mathrm{NaCl}$ concentration 
in experimental enrichment cultures. FEMS Microbiol Ecol 78:428-438

Tindall BJ, Rosselló-Mora R, Busse HJ, Ludwig W, Kämpfer P (2010) Notes on the characterization of prokaryote strains for taxonomic purposes. Int J Syst Evol Microbiol 60:249-266

Vavourakis CD, Ghai R, Rodriguez-Valera F, Sorokin DY, Tringe SG, Hugenholtz P, Muyzer G (2016) Metagenomic insights into the uncultured diversity and physiology of microbes in four hypersaline soda lake brines. Front Microbiol 7:211

Vörös L, Callieri C, Balogh KV, Bertoni R (1998) Freshwater picocyanobacteria along a trophic gradient and light quality range. Hydrobiologia 369:117-125

Vörös L, Somogyi B, Boros E (2008) Birds cause net heterotrophy in shallow lakes. Acta Zoo Acad Sci Hung 54:23-34

Wellburn AR (1994) The spectral determination of chlorophylls $a$ and $b$, as well as total carotenoids, using various solvents with spectrophotometers of different resolution. J Plant Physiol 144:307-313

Wirth JS, Whitman WB (2018) Phylogenomic analyses of a clade within the roseobacter group suggest taxonomic reassignments of species of the genera Aestuariivita, Citreicella, Loktanella, Nautella, Pelagibaca, Ruegeria, Thalassobius, Thiobacimonas and Tropicibacter, and the proposal of six novel genera. Int J Syst Evol Microbiol 68:2393-2411

Wu QL, Zwart G, Schauer M, Kamst-van Agterveld MP, Hahn MW (2006) Bacterioplankton community composition along a salinity gradient of sixteen high-mountain lakes located on the Tibetan Plateau, China. Appl Environ Microbiol 72:5478-5485

Yoon SH, Ha SM, Kwon S, Lim J, Kim Y, Seo H, Chun J (2017) Introducing EzBioCloud: a taxonomically united database of $16 \mathrm{~S}$ rRNA and whole genome assemblies. Int J Syst Evol Microbiol 67:1613-1617

Publisher's Note Springer Nature remains neutral with regard to jurisdictional claims in published maps and institutional affiliations. 